\title{
石油ナフテン酸の研究(第一二報)北海道系石油 ナフテン酸並に固體ナフテン酸の存在
}

工學愽士 田中芳 雄

工學士桑用勉

$$
\text { 第一 緒 言 }
$$

近年北海道に於ける石油つ產出は顯著索る增產を示し現今年產 4 萬石つ産出あり而して其つ主

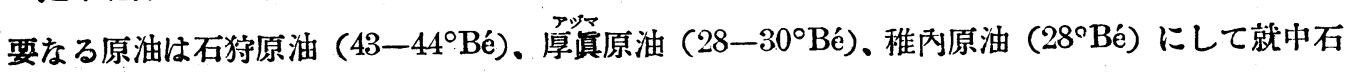
狩原油は其の最も主要なるものなり北海道產石油の特徵は揮發油分に富みたるてとにして石狩 原油は揮發油分約 $50 \%$ を含有し又厚真附近の某原油の如をは $60 \%$ の揮發分を含有せり猶他の 特徽は芳香族並に不飽和族炭化水素に乏しく精慗極めて容易にしてガンリンの如きは何等の化學 的處理を行はすして品位優良なるを以て其僧に自動車用に供せられつっすり又固形パラフィンに 富む

著者の一人（田中）は他の研究者と共に本邦產の石油中に存在するナフテン酸に關して既に多 毄の報告をなしたりしが未だ北海道系の石油ナフテン酸に關しては從來其の研究を見ず上記の如 き特殊の性狀を有する北海道產石油に含まるつナフテン酸が何等か特别の性狀を有す可きを推定 し本研究を行ひたり本研究は北海道石狩國輕川に於ける日本石油株式會杜製油所の好意に依り寄 贈せられたる石油酸を資料としたるものにして之れよりナフテン酸を抽出し純混合ナフテン酸亚 に其のメチルェステルの性狀を研究し是等が既報の本邦各地石油よりのナフテン酸及び其のメチ ルェステルの性狀に比し著しく相異するものあるを認めをり即ち純混合ナフテン酸の比重 $\left(d_{4^{\circ}}^{230}\right)$ 0.9272。屈折率 $\left(n_{D}^{2 n}\right)$ 1.4636、中和價231.0にして $8.9-9.0 \mathrm{~mm}$ の減壓に於て 主溜分 (83.0\%)は $180-230^{\circ} \mathrm{C}$ に溜出し混合ナフテン酸メチルェステルは比重 $\left(d_{1^{\circ}}^{200}\right) 0.9062$ 。屈折率 $\left(n_{D}^{20 \circ}\right) 1.4540$ に して主溜分 (69\%) の沸點範圍は 8.9-9.0 $\mathrm{mm}$ に於て $150-200^{\circ} \mathrm{C}$ なり即ち純混合ナフテン酸及 びメチルェステルの沸點範圍は既報の秋田黑川。桂根、越後新津、西山、頸城等各石油を根原とする ナフテン酸及び其のメチルェステルの夫等に比し夫ィ同等又は同等以上の高沸點範圍なるに拘ら す比重及び屈折率は夫等碰報の石油ナフテン酸の夫等に比し何れも著しく小なるのみならす更に 特筆す可きはナフテン酸及びメチルェステルの各主溜分に於て沸點の上るに從ひ屈折率は順次に 增加するに反し比重は反て減少するてと、並に常溫 $\left(20^{\circ} \mathrm{C}\right)$ に於て美筴なる針状結晶に析出する 比重小なる固體ナフテン酸の多量に存在するてとなり而して著者等の既報䛺研究に於て本邦石泪 ナフテン酸の高沸點溜分には何れも比重の特に小なるナフテン酸の存在を推定し笾きしが本研穷 に於て初めて北海道產石油に比重の極めて小をる液體及び固體ナフテン酸を主成分とする酸性物 
質の存在を發見するを得たり殊に結晶性固體ナフテン酸の存在は從來未だ文献に於て知られざり し新事實なりとす

$$
\text { 第二 粗石油酸資料 }
$$

研究資料としたる粗石油酸は日本石油秼式會社北海道輕川製油所に於て採取せるものにして大 正一四年一○月五日同所上り寄贈せられたるものに係り主として石狩原油を根原としたるもの にして其の輕油分(二號發動機油分、29.6 Bé) の硫酸洗を行ひ次に曹達洗を行ひ斯くして得たる 廢曹達液を $50^{\circ} \mathrm{Bé}$ 硫酸を以て分解し得たる黑褐色油體なり當時の粗石油酸得量は原料油に對し $0.132 \%$ なり但し實驗室に於ける結果は更に多量なり

資料たる粗石油酸は比重 0.9592 、酸價 94 にして稍濃稠なる黑褐色油體をなす多量の石油エー テルを加ふる時は一部は溶解し一部は不溶解なり而してナフテン酸は可溶性部分の中に含有せら る

$$
\text { 第三 粗ナフテン酸の分離 }
$$

粗石油酸より粗ナフテン酸を抽出する爲めに著者等心方法 (本誌第二七七編812頁)、即ち粗石油 酸に同容の石油エーテル（沸點 $80^{\circ} \mathrm{C}$ 以下）を加へ猶微量の酒精を加へ充分に振蕰し上層に分離 せる石油エーテル層を分別し更に同樣に其の下層に石油エーテルを加へて抽出し全部の石油エー テル溶液を集め之れより石油エーテルを驅出し微量の酸化銅を扣へて減厴に於て蒸溜し之れに稍 過剩の苛性加里液を加入加溫して充分に醶化し次に適量の水及び酒精を加一酒精の湄度を約 20 \%とし之れを石油ェーテル（沸點 $70^{\circ} \mathrm{C}$ 以下）にて多數包の抽出を行ひ中性油を除去し次に石战 液を蒸發し酒精及び石油ェーテルを驅出し鹽酸にて石簽を完全に分解し粗ナフテン酸を分離し食 鹽水にて充分に洗滌し帠後に水洗し監化石灰にて脫水したり

斯くして得たる粗ナフテン酸の得量は原石油酸に齿して 13\%にして即ち未洗原料油に㖶する 得量を求されば約 $0.02 \%$ 方り

以上の方法に依て得たる粗ナフテン酸は濃椆油體にして比重、屈折率及び酸價は次の如し

$\begin{array}{lc}\text { 比 重 }\left(d_{4^{\circ}}^{200}\right) & 0.9369 \\ \text { 屈折率 }\left(n_{D}^{210}\right) & 1.4665 \\ \text { 酸 貲 } & 230\end{array}$

之れを既報い如き變更クライセン氏フラスコを使用し 8.9-9.0 $\mathrm{mm}$ の減壓に於て分溜に附した b各蒸溜溫度に於ける溜出物\%、溜出物の比重 $\left(d_{4^{\circ}}^{20^{\circ}}\right)$, 屈折率 $\left(n_{D}^{20 \circ}\right)$ 及び酸價は次表の如し

\begin{tabular}{|c|c|c|c|c|}
\hline 洆溜溫度 $\left({ }^{\circ} \mathbf{C}\right)$ & 溜出物\% & 比 重 $\left(d_{4^{\circ}}^{200^{\circ}}\right)$ & 尿折釬 $\left(n_{D}^{200}\right)$ & 酸價 \\
\hline $115-140$ & 2.7 & 0.9749 & 1.4640 & 287.4 \\
\hline $140-160$ & 2.7 & 0.9632 & 1.4604 & 308.0 \\
\hline $\begin{array}{r}160-170 \\
170-180\end{array}$ & $\left.\begin{array}{l}3.0 \\
5.0\end{array}\right\}$ & 0.9530 & 1.4625 & 5 \\
\hline
\end{tabular}

粗ナフテン酸の減壓蒸溜 $(8.9-9.0 \mathrm{~mm})$ 


\begin{tabular}{|c|c|c|c|c|}
\hline & & 桑田 勉 & & \\
\hline $180-190$ & 11.4 & 0.9403 & 1.4630 & 256.2 \\
\hline $190-200$ & 15.0 & 0.9312 & 1.4630 & 239.3 \\
\hline $200-210$ & 17.8 & 0.9268 & 1.4645 & 225.3 \\
\hline $210-220$ & 18.9 & 0.9839 & 1.4662 & 211.2 \\
\hline $220-230$ & 11.7 & 0.9233 & 1.4696 & 197.1 \\
\hline $230-238$ & 6.0 & $0.9227\left(d_{4^{\circ}}^{3 n^{\circ}}\right)$ & $1.4720\left(n_{D}^{30^{\circ}}\right)$ & 174.4 \\
\hline 殘 油 & 5.8(差) & - & - & - \\
\hline
\end{tabular}

即ち粗ナフテン酸の比重 $\left(d_{4^{\circ}}^{20 \circ}\right)$ は0.94以下にして $d_{4^{\circ}}^{150}$ を求むるも 0.94 以下なり之れを秋田兵 川系、越後 新津系の粗ナフテン酸の比重 $\left(d_{4^{\circ}}^{150}\right)$ が 0.99 以上なるに比すれば潘かに低く、又和 田桂根系、越後西山系、頸城系等の粗ナフテン酸の比重 $\left(d_{4^{\circ}}^{15^{\circ}}\right)$ が何れも 0.96 以上なるに比す。 も亦甚だ低く、其の屈折率も既報粗ナフテン酸の夫等が 1.47 以上なるに比して小なり又主溜う の蒸溜範圍は $180-230^{\circ} \mathrm{C}$ にして此間の溜出物は約 $75 \%$ にして即ち主溜分の蒸溜範圍は秋田点 川系、越後新津系の粗ナフテン酸の場合に近似し他の根原の粗ナフテン酸の場合に比すれば稍志 し而して特に注意す可きは沸點の上昇と共に比重が漸次減するるてとにして又 $220^{\circ} \mathrm{C}$ 以上の溜今 よりは常溫 $\left(20^{\circ} \mathrm{C}\right)$ に於て針狀結晶の多量を析出することなり

第四 混合ナフテン酸メチルエステル

上記の粗ナフテン酸を既報の如き常法に從ひメチルェステルとなし次の如き比重及び屈折率を 有するメチルェステルを得をり

$$
\begin{array}{ll}
\text { 此 重 }\left(d_{4 \circ}^{20 \circ}\right) & 0.9062 \\
\text { 屈折率 }\left(n_{D}^{20 \circ}\right) & 1.4540
\end{array}
$$

之れを前と同樣に 8.9-9.0 $\mathrm{mm}$ の減壓に於て分溜に附し各溜分の溜出量. 比重 $\left(d_{10}^{2 n 0}\right)$ 及び屈丰 率 $\left(n_{D}^{200}\right)$ を測定せるに次の結果を得たり

混合ナフテン酸メチルエステルの減壓蒸溜 $(8.9-9.0 \mathrm{~mm})$

$\begin{array}{cccc}\text { 蒸溜茂度 }\left({ }^{\circ} \mathrm{C}\right) & \text { 溜出物\% } & \text { 此 } & \text { 重 }\left(d_{4^{\circ}}^{20^{\circ}}\right) \\ 70-110 & 3.9 & 0.9152 & \text { 屈折率 }\left(n_{D}^{20 \circ}\right) \\ 110-130 & 4.8 & 0.9202 & 1.4350 \\ 130-150 & 10.4 & 0.9145 & 1.4474 \\ 150-160 & 11.8 & 0.9088 & 1.4524 \\ 160-170 & 15.5 & 0.9046 & 1.4529 \\ 170-140 & 16.4 & 0.9013 & 1.4539 \\ 180-190 & 14.2 & 0.8979 & 1.4548 \\ 190-200 & 10.7 & 0.8963 & 1.4556 \\ 200-210 & 6.7 & 0.8953 & 1.4563 \\ 210-215(7 \mathrm{~mm}) & 3.6 & 0.9026 & 1.4584 \\ \text { 殘 油 } & 2.0 \text { (差) } & - & 1.4633\end{array}$

即ち混合テフテン酸メチルエステルの比重は既報の各種混合ナフテン酸メチルェステルの比! $\left(d_{4^{\circ}}^{15^{\circ}}\right)$ か 0.93 以上（頸城 0.9368 一新津 0.9631 ) 交るに比し遙かに低く屈折率も亦他采の混合: フテン酸メチルェステルの屈折䋃 $\left(n_{D}^{150}\right)$ が 1.46 以上（西山 1.4611一新津 1.4792）なるに比し低し而して其の主溜分の蒸溜範圍は $150-200^{\circ} \mathrm{C} に し て$ 此の間に約 $69 \%$ を溜出す此の沸點範 
は新津系ナフテン酸メチルェステルの夫れに近似すれども他の場合に比するに何れも稍高し此の 場合に於ても分溜油の此重は $110-130^{\circ} \mathrm{C}$ 溜分に於て巳に最高に澾し以後沸點の上るに從ひ脽次 に減少するは特に注意す可き事項にして即ち高沸點の部分に此重の小なるナフテン酸の存在を推 定せしむるものなり

\section{第五. 純混合ナフテン酸}

上記ナフテン酸メチルエステルを常法に從ひ沶性加里液と薏沸して加水分解し斯くして得たる

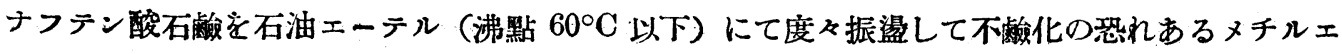
ステルを除去し次に繁發して石油エーテル及び酒精を除去し稀盬酸にて分解し水洗し監化石灰に て眖水し純混合ナフテン酸を得たり

純混合ナフテン酸は粗石油酸に對し得率約 $10 \%$ にして其の比重。屈折率及び中和價は次の如し

$\begin{array}{lc}\text { 比 重 }\left(d_{4^{\circ}}^{20 \circ}\right) & 0.9272 \\ \text { 屈折率 }\left(n_{D}^{20 \circ}\right) & 1.4636 \\ \text { 中和價 } & 231.0\end{array}$

之れを前と同㥞に變更クライセン氏フラスコに低り 8.9-9.0 $\mathrm{mm}$ の減壓に於て分溜し各溜分の 溜出量、比重 $\left(d_{4 \circ}^{20 \circ}\right)$ 、屈折率 $\left(n_{D}^{200}\right)$ 及び中和儨它測定せるに次の結果を得たり

純混合ナフテン酸の減壓蒸溜 $(8.9-9.0 \mathrm{~mm})$

\begin{tabular}{|c|c|c|c|c|}
\hline 蒸溜溫度 $\left({ }^{\circ} \mathrm{C}\right)$ & 溜出物\% & 比 重 $\left(d_{4^{\circ}}^{220}\right)$ & 屈折本 $\left(n_{\nu}^{2 j 0}\right)$ & 中和價 \\
\hline $120-140$ & 1.1 & 0.9563 & 1.4536 & 322.0 \\
\hline $140-160$ & 3.6 & 0.9524 & 1.4559 & 311.4 \\
\hline $160-170$ & 3.2 & 0.9474 & 1.4592 & 288.5 \\
\hline $170-180$ & 5.2 & 0.9418 & 1.4611 & 273.3 \\
\hline $180-190$ & 9.1 & 0.9342 & 1.4618 & 252.1 \\
\hline $190-200$ & 19.3 & 0.9286 & 1.4621 & 236.5 \\
\hline $200-210$ & 21.6 & 0.9230 & 1.4634 & 223.4 \\
\hline $210-220$ & 20.1 & 0.9193 & 1.4648 & 210.9 \\
\hline $220-230$ & 12.4 & $0.9101\left(d_{4^{\circ}}^{30 \circ}\right)$ & $1.4622\left(n_{D}^{30 \circ}\right)$ & 197.4 \\
\hline $230-235$ & 3.2 & $0.9131\left(d_{4^{\circ}}^{355^{\prime}}\right)$ & $1.4650\left(n_{D}^{350}\right)$ & 183.2 \\
\hline 殘 油 & 1.1(差) & - & - & - \\
\hline
\end{tabular}

即ち純混合ナフテン酸の比重 $\left(d_{4^{\circ}}^{200}\right)$ は既報の本邦各地石油よりの純泿合ナフテン酸の比重 $\left(d_{4^{\circ}}^{15^{\circ}}\right)$ が 0.95 以上（頸城 0.9587 一黑川 0.9918）なるに比して遙かに低く屈折率も亦他系の純混 合テフテン酸の屈折率 $\left(n_{D}^{150}\right)$ が 1.47 以上（頸城 1.4707 一新津 1.4887 ) なるに比して低し勿論上 記の北海道產ナフテン酸の比重及び屈折率を $15^{\circ} \mathrm{C}$ の場合に換算して之れを比較するも結諭に於 ては異らす而して主溜分の沸點は $180-230^{\circ} \mathrm{C}$ にして此間の溜H物は約 $83 \%$ なり㴧ち主溜分の 沸點莗圍は秋田黑川系、越後新津系よりの純混合ナフテン酸の場合に近似し他の根原のナフテン 酸の場合に比し高し猶注意す可きてとは沸點の上昇と共に比重が䐓次に減少するてと、並に $2200 \mathrm{C}$ 以上の溜分よりは常溫 $\left(20^{\circ} \mathrm{C}\right)$ に於て美麗なる針狀絈晶の多量を析出するてとにして是等は粗ナ 
フテン酸の場合に於ても認めたる所なり該固體ナフテン酸をメタノール溶液より反復結晶せしむ る時は中和價 198.5 、融點 $53-66^{\circ} \mathrm{C}$ 、比重 $\left(d_{4^{\circ}}^{60^{\circ}}\right) 0.8550$ を有する結晶を得此の固體ナフテン酸は エーテル、アセトン、ベンジール等に容易に溶解し冷酒精又は椧メタノールには比較的奞溶性な り之れを $15 \mathrm{~mm}$ に於て蒸溜するに主溜分は 220 - $250^{\circ} \mathrm{C}$ に溜出す

猶粗テフテン酸と純混合ナフテン酸との比重、屈折率、酸價並に分溜試驗を對照する時は容易 に粗ナフテン酸中にはフェノール性成分の混在せるを推定せしむること既報の場合に同じ

要するに北海道原油中に存在する石油ナフテン酸の主成分は他の本邦各地原油中に存在する石 油ナフテン酸の主成分に比し同樣又は夫れ以上の沸點を有するに拘らす又近似せる中和價を有す るに拘らず其の比重は著しく小にして屈折率も稍小なり

而して溜分の沸點上景と共に屈折率が菂为し酸價の隇少するてとは既報の凡ての場合と同樣な れビも溜分の沸點上昇と共に比重が順次に減少するてとは異例なりとす但し既報凡ての場合に於 て $200^{\circ} \mathrm{C}$ 又は $210^{\circ} \mathrm{C}$ 以上の溜分に於ては此重を減少するを認め從て著者の一人（田中）は比 重の小なる高沸點ナフテン酸の侾在を指摘し晸きたりしが本研究に於て北海道系ナフテン酸には 比重の小なるナフテン酸の多量が存在するてとを發見し殊に高沸點溜分よりは結晶性固體ナフテ ン酸の多量の析出を認めたるは興味あるのみなら結晶ナフテン酸は一層小なる比重を付するを 認めたり恐らく既報凡ての場合に於ける本邦各地のナフテン酸にも其の高沸點溜分には斯の如き 固體ナフテン酸が微量に存在するものなる可し

斯の如き北海道系石油ナフテン酸の特性は其の原油の特性と共に該石油の地質的生因及び徑路 に關して興味深き關係を有するものなる可し

固體ナフテン酸に關しては改めて報告す可し

\section{第六 總括}

(1) 北海道石狩系原油を主として根原とせる輕油分(日本石油秼式會融二號發動機油分.29.6 ${ }^{\circ} \mathrm{Bé}$ ) の曹達洗淮に於て 生ずる 廢曹達液に稿硫酸を加へて酸性と 爲し 分離せる 酸性物質、即ち粗 石油酸を研究資料とし之れより比重 $\left(d_{4^{\circ}}^{20^{\circ}}\right) \quad 0.9369$ 、屈折率 $\left(n_{D}^{200^{\circ}}\right) 1.4665$ 、酸價 230 、主溜分(75\%) の蒸溜範圍 180 - $230^{\circ} \mathrm{C}(8.9-9.0 \mathrm{~mm})$ の粗ナフテン酸を得たり粗石油酸に對する得量 $13 \%$ にし て未洗原料油に對し約 $0.02 \%$ なり溜分の沸點高き程比重低下し高沸點溜分に於て固體ナフテン 設の析出するを認めたり

（2）混合ナフテン酸メチルエステルは此重 $\left(d_{40^{\circ}}^{20 \circ}\right) 0.9062$ 。屈折率 $\left(n_{D}^{20 \circ}\right) 1.4540$ を有し 8.9-9.0 $\mathrm{mm}$ に於て 150 - $200^{\circ} \mathrm{C}$ に主溜分 (69\%) 老溜出す即ち主溜分の沸點範圍は既報の越後新津系 よりのナフテン酸メチルェステルの場合に近似し他の根原の場合に比し高きに拘らず比重は既報 の何れの場合よりも著しく低く届折率も稍低し又分溜油の比重は沸點つ上开に從ひ順次減少す

（3）純混合ナフテン酸は比重 $\left(d_{4^{\circ}}^{20 \circ}\right) 0.9272$, 屈折率 $\left(n_{D}^{200}\right) 1.4636$ 、中和價 231.0 を有し其の主溜 
分の溜出溫度は $8.9-9.0 \mathrm{~mm}$ に於て $180-230^{\circ} \mathrm{C} に$ して約 $83 \%$ を溜出す即ち純混合ナフテン酸 の沸點範圍は秋田黑川系、越後新津系よりの純混合ナフテン酸の場合に近似し他の根原の石油ナ フテン酸の場合に比し稍高きに拘らず其の比重及び届折率は既報の本邦各地石油よりの純混合ナ フテン酸の夫等に比し著しく低し且注目す可きことは溜出油の沸點高きもの程比重の小なるてと にして即ち高沸點を有する比重小なるナフテン酸の存在を示し又高沸點溜分よりは比重の甚だ小 なる結晶性固體ナフテン酸の多量に析出するてと是れなり該固體ナフテン酸は中和價 198.5. 骶 點 53-66 $6^{\circ} \mathrm{C}$ 、比重 $\left(d_{4^{\circ}}^{300}\right) 0.8550$ を有し $15 \mathrm{~mm}$ に於て主溜分は $220-250^{\circ} \mathrm{C}$ に溜出す

（4）北海道系石油ナフテン酸の主溜分が既報本邦各地の石油ナフテン酸に比し同様又は夫れ以 上の沸點を有するに拘らず刃近似せる中和價を有するに拘らず比重に於て著しく低く又比重の甚 だ小なる結晶性固體ナフテン酸の多量に存在するてとは從來他に類例を見ざる事賽にして北海道 產原油の特性と共に恐らく石油の地質的生因並に徑路に關して重要なる關係を有するるのなる可 きを推定せり

本研究は帝國學士院の研究費に依りたるるのにして唒資料其他に關して日本石油秼式會社取緛 役水田政吉氏及び同社技師杉本保也氏に貰ふ所逻だ多し茲に謹で感謝の意を表す

（大正一五年八月二○日 東京帝國大學工學部應用化學科研究室) (大正一五年九月三日受理) 